\title{
Information and Communication Technology Use in Suicide Prevention: Scoping Review
}

Jessica Rassy ${ }^{1,2,3,4^{*}}, \mathrm{PhD}$; Cécile Bardon ${ }^{1,5^{*}}, \mathrm{PhD}$; Luc Dargis ${ }^{1 *}$, MSc; Louis-Philippe Côté ${ }^{1,5^{*}}$, MSc; Laurent Corthésy-Blondin ${ }^{1,5^{*}}$, MSc; Carl-Maria Mörch ${ }^{1,5,6,7^{*}}, \mathrm{PhD}$; Réal Labelle ${ }^{1,2,5,8}, \mathrm{PhD}$

${ }^{1}$ Center for Research and Intervention on Suicide, Ethical Issues and End-of-Life Practices, Université du Québec à Montréal, Montréal, QC, Canada

${ }^{2}$ Research Center, Institut universitaire en santé mentale de Montréal, Montréal, QC, Canada

${ }^{3}$ School of Nursing, Université de Sherbrooke, Longueuil, QC, Canada

${ }^{4}$ Quebec Network on Nursing Intervention Research, Montréal, QC, Canada

${ }^{5}$ Department of Psychology, Université du Québec à Montréal, Montréal, QC, Canada

${ }^{6}$ Algora Lab, Université de Montréal, Montréal, QC, Canada

${ }^{7}$ Mila, Quebec Artificial Intelligence Institute, Montréal, QC, Canada

${ }^{8}$ Department of Psychiatry, Université de Montréal, Montréal, QC, Canada

* these authors contributed equally

\section{Corresponding Author:}

Réal Labelle, $\mathrm{PhD}$

Department of Psychology

Université du Québec à Montréal

CP 8888, succ Centre-Ville

Montréal, QC, H3C 3P8

Canada

Phone: 15149874184

Email: labelle.real@uqam.ca

\section{Abstract}

Background: The use of information and communication technology (ICT) in suicide prevention has progressed rapidly over the past decade. ICT plays a major role in suicide prevention, but research on best and promising practices has been slow.

Objective: This paper aims to explore the existing literature on ICT use in suicide prevention to answer the following question: what are the best and most promising ICT practices for suicide prevention?

Methods: A scoping search was conducted using the following databases: PubMed, PsycINFO, Sociological Abstracts, and IEEE Xplore. These databases were searched for articles published between January 1, 2013, and December 31, 2018. The five stages of the scoping review process were as follows: identifying research questions; targeting relevant studies; selecting studies; charting data; and collating, summarizing, and reporting the results. The World Health Organization suicide prevention model was used according to the continuum of universal, selective, and indicated prevention.

Results: Of the 3848 studies identified, 115 (2.99\%) were selected. Of these, 10 regarded the use of ICT in universal suicide prevention, 53 referred to the use of ICT in selective suicide prevention, and 52 dealt with the use of ICT in indicated suicide prevention.

Conclusions: The use of ICT plays a major role in suicide prevention, and many promising programs were identified through this scoping review. However, large-scale evaluation studies are needed to further examine the effectiveness of these programs and strategies. In addition, safety and ethics protocols for ICT-based interventions are recommended.

(J Med Internet Res 2021;23(5):e25288) doi: 10.2196/25288

\section{KEYWORDS}

suicide prevention; information and communication technology; scoping review; mobile phone 


\section{Introduction}

\section{Background}

Information and communication technology (ICT) has been used for suicide prevention over the past decade. Moreover, there is a growing body of evidence supporting the use of ICT in the development of promising suicide prevention practices $[1,2]$. ICT can be used to screen individuals at risk of suicide on the web; offer information and help regarding suicidal thoughts and behavior; and offer web-based assessment, interventions, and follow-up [1-6]. The use of ICT widens accessibility to hard-to-reach individuals who do not always seek help in person and offers treatment opportunities to communities with lower access to care, such as rural communities. The use of ICT in suicide prevention can also help professionals offer better care to their patients by combining multiple approaches, such as using mobile apps to monitor symptoms or providing web-based therapeutic programs $[7,8]$.

Many opportunities arise when using ICT to expand suicide prevention strategies. However, the pace at which ICT is advancing makes it difficult to keep up with, especially from a research perspective. To make better use of these different web-based suicide prevention strategies, a better understanding of these different uses of ICT is necessary. We identified 3 major questions. First, a better understanding of how to emphasize the technical aspects of ICT regarding the development, maintenance, privacy, and life cycle of the technology would help make better choices regarding which ICT to use in what context. For example, machine learning offers many possibilities for identifying at-risk individuals, but major technical and ethical considerations must be described and taken into account. Second, we need to improve our understanding of ICT use in suicide prevention. To support adequate decision making, it is important to know whether ICT-based suicide prevention strategies reach different clienteles or if we are reaching the same individuals differently. Third, a better understanding of the structure and efficacy of various types of current web-based assessments and interventions is also important. For instance, can artificial intelligence (AI) and machine learning be used to optimize and accelerate the assessment of individuals at risk? Is a suicide crisis intervention by chat as effective as talking over the phone or in person? Are web-based cognitive behavioral therapy (CBT) programs as effective for suicide prevention as face-to-face CBT programs? Before shifting toward using and recommending the use of these different ICT-based assessments and interventions, it should be noted that their effectiveness has yet to be demonstrated in the literature.

\section{Current Study}

The available literature often refers to a specific type of ICT as opposed to a general overview of existing ICT-based strategies in mental health and suicide prevention. More precisely, existing literature reviews have focused on specific ICTs such as smartphone tools [1], web-based interventions [3], mobile apps [4], and social media [5] or specific age groups such as youth [6]. Based on this background and a rapidly evolving corpus of research, we set out to review the evidence supporting the use of all types of ICTs in different levels of suicide prevention strategies. More precisely, we carried out a scoping review to identify the best and most promising practices for ICT use at all levels of suicide prevention, which are described by the World Health Organization as the universal (entire population), selective (specific subpopulations), and indicated (high-risk individuals) levels [9]. ICT was defined as all materials, software, or services used to collect, process, and transmit information; this includes electronic, computer, telecommunications, multimedia, and internet technologies [10]. AI was defined as all theories and techniques used to develop machines capable of simulating intelligence [7].

\section{Methods}

\section{Scoping Review Framework}

We used the 5-stage scoping framework developed by Arksey and O'Malley [11] and adapted by Levac et al [12] to review peer-reviewed publications. These stages are (1) identifying research questions; (2) identifying relevant studies; (3) selecting studies; (4) charting data; and (5) collating, summarizing, and reporting results. A scoping review allows researchers to explore the available data on various aspects of a theme instead of just one $[11,12]$. This provides an overview of the relevant literature that helps to identify the various ICT and suicide prevention strategies examined by researchers since 2013 and to document their effects. The Center for Research and Intervention on Suicide, Ethical Issues, and End-of-Life Practices decided to better understand the use of ICT in suicide prevention as of 2013 following the publication of the book Suicide prevention and new technologies: Evidence-based practice [13]. This book provides an overview of new technologies in suicide prevention and demonstrates the need for further research in this area. As ICT tools, contents, and use evolve rapidly, a 5-year timeframe seems relevant to address the current state of ICT preventive practices and research. For example, major social networks have changed their policies toward content related to suicidality. During the 2019 International Suicide Prevention Day, Facebook revised its policy of preventing self-harm and suicide by banning graphic representations of suicidality, which could change the level of exposure of individuals vulnerable to suicide. At the same time, the rapid development of scientific knowledge and technology has been noted many times. For example, a review of the scientific literature published in 2013 identified 5 scientifically evaluated mobile apps for child and adolescent mental health [14], whereas Grist et al [15] identified 19 more. In addition, web-based platforms such as Parler or 4Chan were not as widely known and used 10 years ago. Including older technologies and neglecting to consider the rapid content change of internet content over the years may skew results toward obsolete prevention strategies.

\section{Summary of Search Strategy}

\section{Identifying the Research Question}

The research question identified for this scoping review aims to guide future program development and implementation by establishing an inventory of strategies using ICT that have been the subject of research in recent years. Following the PRISMA 
(Preferred Reporting Items for Systematic Reviews and Meta-Analyses) recommendations, the research question was developed using the PICO (population, intervention, comparison, and outcomes) conceptual tool [16]. Note that an adaptation of PICO was made through an amalgamation with the SPIDER (sample, phenomenon of interest, design, evaluation, research type) tool by Methley et al [17] to facilitate the consideration of the psychosocial nature of the research object. Consequently, the research question was "How information and communication technology (ICT) can be used in intervention and prevention of suicide among the general population, people at risk, or suicidal people of all ages and conditions combined to contribute to the reduction of any indicators relating to suicidality?" This question was selected to promote the instrumental use of the research results [18].

\section{Identifying Relevant Studies}

The search strategy consisted of identifying key concepts related to ICT-based suicide prevention and intervention, developing a provisional syntax specific to each database for pretesting, and determining the definitive syntax based on the pretest results. The keywords used to construct research syntaxes were extracted from natural (everyday vocabulary) and controlled (indexer terms) language terms and based on the central concepts associated with the research questions. The researched concepts were suicidal behavior, ICT (AI, machine learning, application, social network, and mobile technology), intervention (information, education, prevention, decision making, and intervention), and program evaluation. The final syntax based on these keywords and used with each database searched is presented in Multimedia Appendix 1. PubMed, PsycINFO, Sociological Abstracts, and IEEE Xplore were searched for publications from January 1, 2013, to December 31, 2018. The selection of each database was carefully thought out by the research team (2 senior researchers in suicidology, 2 ICT experts, 1 postdoctoral student, 1 doctoral student, and 1 specialized librarian who provided support) to include data in the medical field, psychology, social and behavioral sciences, and ICT. The number of databases chosen was in line with that of other reviews that focused on specific ICTs and mental health $[5,19]$. In addition, the choice of databases was based on the following 2 criteria: the number of documents they contain and the degree of overlap of the content indexed in each database [20]. The final choice was made to select high quantities of indexed documents in databases and databases with less content overlap to maximize the completeness of the retrieval process.

\section{Selecting Studies}

The final search syntax identified 3848 publications that were imported for EndNote selection. From these, 1391 duplicates were removed. The remaining 2457 publications were then sorted according to the inclusion and exclusion criteria applied by 5 research assistants against titles and abstracts only. Interrater reliability was assessed for 100 publications. Agreement reached $89 \%$ and a Cohen $\kappa$ statistic of 0.704 was achieved, which is considered substantial by Cohen [21]. The studies covered in our review used various methods (qualitative, quantitative, and mixed methods) and were drafted in English or French. They had to provide original empirical or descriptive data. Literature reviews, editorials, theoretical articles, and studies focused only on ethical or legal issues surrounding ICT-based suicide prevention were excluded. The included articles had to directly address suicide prevention strategies using ICT. All studies that used death by suicide, suicidal ideation, or suicide behavior as outcomes were considered. The PRISMA flow chart [16] of our study presented in Figure 1 provides an overview of our study selection process. 
Figure 1. PRISMA (Preferred Reporting Items for Systematic Reviews and Meta-Analyses) flow diagram.

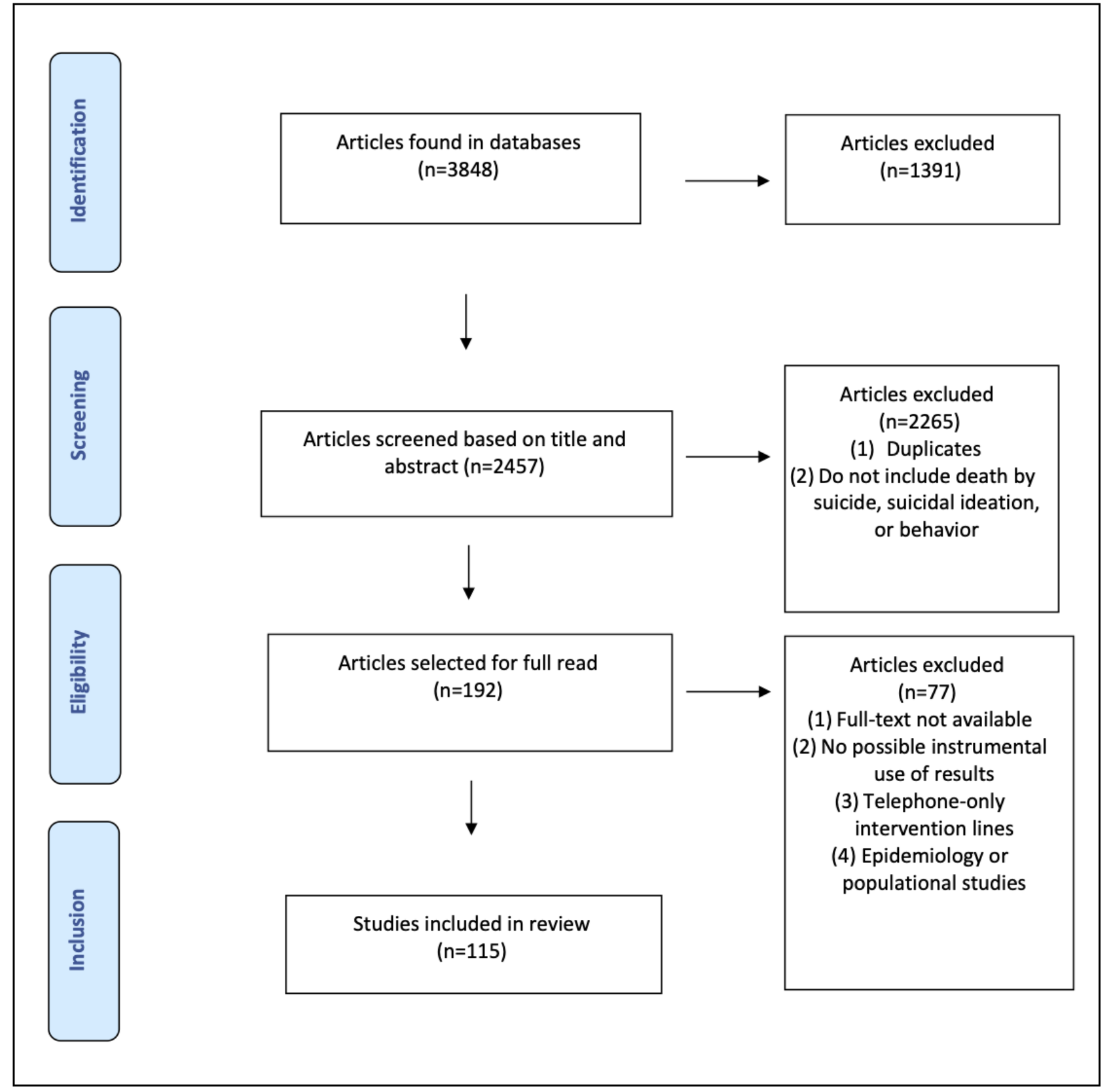

\section{Charting, Collating, Summarizing, and Reporting Data}

A form was developed in Microsoft Excel to retrieve pertinent information from selected qualitative, quantitative, and mixed methods studies to optimize data charting. A research team tested the form before use. It included 10 items: title, objectives, research design, instruments of measure, type of suicide prevention (universal, selective, or indicated), technology category, participant characteristics, results associated with effects and benefits regarding lowering suicidal behavior, clinical and scientific contributions, and recommendations. The research team thoroughly examined 5 independent studies with 10 items and then compared the results. Following this analysis, precision was applied to the exclusion criteria of the studies. Verbal telephone interventions were excluded from this review. Considering the large quantity of data available on suicide prevention telephone interventions [22-24], studies addressing these types of interventions were excluded from this scoping review. However, interventions based on text messaging and smartphone apps were included as new ICT-based interventions relevant to this review. After criteria validation, a summary of pertinent information was prepared for each study included. No systematic methodological quality evaluation was carried out in accordance with the scoping review methodology [11].

\section{Results}

\section{General Information}

Our search of PubMed, PsycINFO, Sociological Abstracts, and IEEE Xplore yielded 3848 articles. After removing 1391 duplicates and 2265 articles based on a perusal of title and abstract, 192 texts were read in full for the final screening. This allowed us to remove an additional 77 articles, leaving 115 articles for the scoping review. We also noticed through our 
analysis that the number of publications increased in 2016 and 2017 , and the scientific articles focused more on selective and indicated suicide prevention strategies.

\section{Classification of Interventions' Efficacy}

In the context of this scoping review, we aim to provide a general portrait of existing suicide prevention strategies based on ICT. It does not aim to determine the quantitative effectiveness of such interventions. Therefore, a prevention strategy is considered effective when it is based on rigorous theory and when it has been evaluated by a minimum of 2 studies with a quasi-experimental approach [25]. Typically, in traditional systematic reviews, identifying evidence-based practices requires a weighting of the methodological quality of primary studies, unlike the scoping review [12]. If the relevant studies are randomized trials, the body of evidence begins with high certainty. If the relevant studies are observational, the body of evidence begins with low certainty [26]. Certain strategies may, however, be presented as promising when at least one observational or randomized study supports its efficacy. Therefore, we considered all interventions that have demonstrated effectiveness in any type of research design (qualitative, quantitative, or mixed studies).

\section{Universal Suicide Prevention Strategies}

In total, 10 of the studies selected referred to universal suicide prevention strategies (Table 1). These addressed 2 main program categories: (1) health promotion and suicide prevention through the use of educational websites and (2) health promotion and suicide prevention through awareness campaigns and social media psychoeducation. These programs were accessible to all participants. The types of websites identified were information-based, interactive, forums, and chats. Social media platforms included Facebook, Twitter, and personal and professional blogs. In general, the effects of these programs on perceptions and knowledge have been poorly evaluated. Universal suicide prevention strategies included the SUPREME (Suicide Prevention through Internet and Media-Based Mental Health Promotion) project [27], the Storytelling project [28], the It Gets Better project [29], the Live Through This project [30], and Media-Based Prevention Messages [31]. Although these different universal strategies could have some effects on the negative emotions of participants [32], they primarily play a potential role in reducing the stigma associated with suicide $[30,33]$ and suicidal ideation and behavior [27,30,32] and increasing web-based suicide prevention knowledge [31,34,35], mental health literacy [32,33], and web-based help seeking $[33,34]$. Table 1 presents a description of the studies that referred to universal suicide prevention strategies.

Table 1. Universal suicide prevention strategies.

\begin{tabular}{|c|c|c|c|c|c|c|c|}
\hline Type of program & $\begin{array}{l}\text { Identified } \\
\text { studies }\end{array}$ & Objectives & $\begin{array}{l}\text { Pro- } \\
\text { grams, } n\end{array}$ & ICT $^{\mathrm{a}}$ used & $\begin{array}{l}\text { Targeted } \\
\text { population }\end{array}$ & Examples & $\begin{array}{l}\text { Results and com- } \\
\text { ments }\end{array}$ \\
\hline $\begin{array}{l}\text { Health promotion } \\
\text { and suicide preven- } \\
\text { tion through the use } \\
\text { of educational web- } \\
\text { sites }\end{array}$ & {$[27,28,30,32]$} & 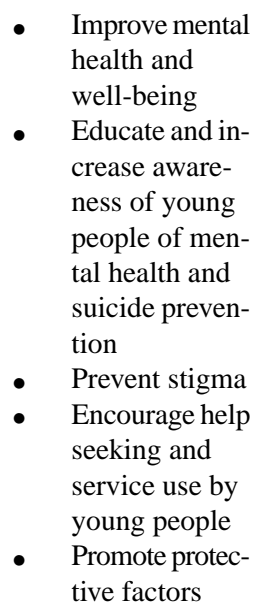 & 2 & $\begin{array}{ll}\text { - } & \text { Websites } \\
\text { - } & \text { Interactive } \\
\text { modules } \\
\text { - } & \text { Forums }\end{array}$ & $\begin{array}{ll}\text { - } & \text { Young } \\
& \text { people } \\
\text { - } & \text { Young } \\
& \text { adults } \\
\text { - } & \text { At-risk } \\
& \text { groups }\end{array}$ & $\begin{array}{l}\text { "SUPREME" }{ }^{\mathrm{b},} \\
\text { project [27] and } \\
\text { "Live Through } \\
\text { This" [30] }\end{array}$ & $\begin{array}{l}\text { Results in terms of } \\
\text { reducing suicidal } \\
\text { ideation and behav- } \\
\text { ior, increasing men- } \\
\text { tal health literacy, } \\
\text { and increasing web- } \\
\text { based help seeking } \\
\text { seemed promising. }\end{array}$ \\
\hline $\begin{array}{l}\text { Health promotion } \\
\text { and suicide preven- } \\
\text { tion through aware- } \\
\text { ness campaigns and } \\
\text { social media psy- } \\
\text { choeducation }\end{array}$ & {$[29,31,33-36]$} & $\begin{array}{l}\text { Increase social } \\
\text { media users' } \\
\text { awareness of } \\
\text { the existence of } \\
\text { and issues asso- } \\
\text { ciated with sui- } \\
\text { cide and its } \\
\text { prevention }\end{array}$ & 4 & $\begin{array}{l}\text { - Presenting, } \\
\text { broadcasting } \\
\text { and sharing } \\
\text { messages on } \\
\text { social media }\end{array}$ & $\begin{array}{ll}\text { - } & \text { Young } \\
& \text { people } \\
\text { - } & \text { At-risk } \\
\text { groups }\end{array}$ & $\begin{array}{l}\text { "It Gets Better" } \\
\text { project [29] and } \\
\text { "Media-Based } \\
\text { Prevention } \\
\text { Messages" [31] }\end{array}$ & $\begin{array}{l}\text { Results in terms of } \\
\text { reducing suicidal } \\
\text { ideation and behav- } \\
\text { ior and improving } \\
\text { knowledge, atti- } \\
\text { tudes, and asking for } \\
\text { help on the web } \\
\text { seemed promising. } \\
\text { However, further re- } \\
\text { search was needed. }\end{array}$ \\
\hline
\end{tabular}

${ }^{\mathrm{a}}$ ICT: information and communication technology.

${ }^{\mathrm{b}}$ SUPREME: Suicide Prevention through Internet and Media-Based Mental Health Promotion. 


\section{Selective Suicide Prevention Strategies}

We identified 53 studies that dealt with selective suicide prevention strategies (Table 2). From these, 9 different selective suicide prevention program categories emerged, and each had multiple different outcomes. These strategies ranged from identifying people at risk to web-based self-management and training programs. Some were designed to be used alone, whereas others were part of a larger intervention program involving direct contact between suicidal individuals and suicide prevention resources. The programs targeted distressed individuals and groups at risk, that is, health professionals. ICT use varied according to the desired outcome. For example, algorithms were used to identify individuals at risk for suicide on the web, as advertised by Google AdWords, which is now known as Google Ads [37,38]; interactive websites were used to support the assessment and management of mental health disorders in collaboration with a mental health professional [39]; and training modules, web-based exercises, and multimedia presentations were used to enhance knowledge, understanding, and attitudes regarding suicide prevention and intervention [40-42]. Programs using algorithms to identify at-risk individuals seemed most promising for identifying people at risk for suicide versus those not at risk [37,38,43-58]. These algorithms analyzed suicide risk on the basis of different elements, including speech and linguistic characteristics, medical notes, search engine ad clicks, and profiles from web-based chat sessions or social media [37,38,43-58]. Although these algorithms helped identify individuals at risk for suicide, a clinical application of these algorithms is yet to be developed, as little is known about the effectiveness of these programs in increasing actual web-based and in-person help-seeking behaviors. 
Table 2. Selective suicide prevention strategies.

\begin{tabular}{|c|c|c|c|c|c|c|c|}
\hline Type of program & $\begin{array}{l}\text { Identified } \\
\text { studies }\end{array}$ & Objectives & Programs, $\mathrm{n}$ & $\mathrm{ICT}^{\mathrm{a}}$ used & $\begin{array}{l}\text { Targeted popula- } \\
\text { tion }\end{array}$ & Examples & $\begin{array}{l}\text { Results and com- } \\
\text { ments }\end{array}$ \\
\hline $\begin{array}{l}\text { Identifying at-risk } \\
\text { individuals through } \\
\text { automatic analysis } \\
\text { of their linguistic } \\
\text { characteristics dur- } \\
\text { ing face-to-face } \\
\text { consultations }\end{array}$ & [44-47] & $\begin{array}{l}\text { Identify indi- } \\
\text { viduals at risk } \\
\text { for suicide } \\
\text { and qualify } \\
\text { risk level } \\
\text { based on } \\
\text { speech charac- } \\
\text { teristics }\end{array}$ & 2 & $\begin{array}{l}\text { - Analysis of } \\
\text { characteristics } \\
\text { from observa- } \\
\text { tion of spoken } \\
\text { language }\end{array}$ & $\begin{array}{l}\text { - } \text { Individu- } \\
\text { als present- } \\
\text { ing risk } \\
\text { factors at } \\
\text { assessment } \\
\text { interviews }\end{array}$ & $\begin{array}{l}\text { Analysis of } \\
\text { speech and } \\
\text { sound character- } \\
\text { istics program } \\
{[45-47]}\end{array}$ & $\begin{array}{l}\text { This technology } \\
\text { seems effective in } \\
\text { distinguishing suici- } \\
\text { dal from nonsuici- } \\
\text { dal individuals. A } \\
\text { clinical use of this } \\
\text { technology is yet } \\
\text { to be developed. }\end{array}$ \\
\hline $\begin{array}{l}\text { Identifying at-risk } \\
\text { individuals through } \\
\text { automatic analysis } \\
\text { of medical file } \\
\text { notes and/or re- } \\
\text { search data }\end{array}$ & [54-57] & $\begin{array}{l}\text { - Identify indi- } \\
\text { viduals at risk } \\
\text { for suicide } \\
\text { and qualify } \\
\text { risk level } \\
\text { based on data } \\
\text { (medical file } \\
\text { or research }\end{array}$ & 1 & $\begin{array}{l}\text { - Analysis of } \\
\text { written lan- } \\
\text { guage }\end{array}$ & $\begin{array}{l}\text { - Individu- } \\
\text { als present- } \\
\text { ing risk } \\
\text { factors } \\
\text { during as- } \\
\text { sessment } \\
\text { interviews }\end{array}$ & $\begin{array}{l}\text { The "Safety- } \\
\text { Net" program } \\
{[56]}\end{array}$ & $\begin{array}{l}\text { This technology } \\
\text { seems effective in } \\
\text { distinguishing suici- } \\
\text { dal from nonsuici- } \\
\text { dal individuals. A } \\
\text { clinical use of this } \\
\text { technology is yet } \\
\text { to be developed. }\end{array}$ \\
\hline
\end{tabular}

Identifying at-risk individuals through automatic analysis of their linguistic characteristics during chat sessions or on written forms

Identifying at-risk individuals through automatic analysis of their linguistic characteristics on social media

\section{$[43,58]$}

data) from

clinical obser-

vations by

clinicians or

researchers

- Identify indi- 0

viduals at

high risk for

suicide based

on characteris-

tics of their

words or re-

sponses

[48-53,59-62] • Examine writ- 4 ings of social media users

to automatical-

ly identify in-

dividuals at

risk for sui-

cide and offer

them proac-

tive help

Identifying at-risk $\quad[37,38]$ individuals through targeted ads on search engines
- Identify suici- 2 dal individuals through their queries on search engines

- $\quad$ Suggest help resources
- Analysis of written language

Analysis of written language

Search engine algorithm and targeted ads
- Individuals presenting risk factors during written exchanges

- Social media users

Program to
screen suicida based on tweets [52,59]

Web-based sen- The number of tinel program clicks on targeted [37] screen suicidal individuals

Suicide mean- This technology plied in specific A clinical use of contexts [58] this technology is yet to be developed.

This technology is innovative. Further research is needed. ing making ap- seems promising.
General public
Web-based identifi- [63-69] cation programs tailored to different groups
- $\quad$ Identify vul- 3

nerable groups using mailing lists or websites to direct them toward help resources
- Web-based standardized risk assess- ment question- naires with re- sponse algo- rithms adapt- ed to assess- ment results

$\begin{array}{ll}\text { EMPATHY }^{\mathrm{b}} & \text { This type of pro- } \\ \text { [63] and } & \text { gram allows identi- } \\ \text { HEAR }^{\mathrm{c}} \text { for } & \text { fying individuals at } \\ \text { nurses [69] } & \text { risk who have no } \\ & \text { contact with health } \\ & \text { services. Utiliza- } \\ & \text { tion rates for pro- } \\ & \text { posed resources } \\ & \text { seem encouraging. }\end{array}$




\begin{tabular}{|c|c|c|c|c|c|c|c|}
\hline Type of program & $\begin{array}{l}\text { Identified } \\
\text { studies }\end{array}$ & Objectives & Programs, n & $\mathrm{ICT}^{\mathrm{a}}$ used & $\begin{array}{l}\text { Targeted popula- } \\
\text { tion }\end{array}$ & Examples & $\begin{array}{l}\text { Results and com- } \\
\text { ments }\end{array}$ \\
\hline $\begin{array}{l}\text { Web-based mental } \\
\text { health self-evalua- } \\
\text { tion programs }\end{array}$ & {$[39,70]$} & $\begin{array}{l}\text { Support evalu- } \\
\text { ation and } \\
\text { management } \\
\text { of mental } \\
\text { health prob- } \\
\text { lems in con- } \\
\text { junction with } \\
\text { a mental } \\
\text { health profes- } \\
\text { sional }\end{array}$ & 1 & $\begin{array}{ll}\text { - } & \begin{array}{l}\text { Interactive } \\
\text { website }\end{array} \\
\text { Web-based } \\
\text { evaluation } \\
\text { tool } \\
\text { - Algorithm } \\
\text { tool for redi- } \\
\text { recting to re- } \\
\text { sources } \\
\text { Development } \\
\text { of a web- } \\
\text { based person- } \\
\text { alized inter- } \\
\text { vention plan }\end{array}$ & $\begin{array}{l}\text { Individu- } \\
\text { als receiv- } \\
\text { ing sup- } \\
\text { port from } \\
\text { a health } \\
\text { profession- } \\
\text { al }\end{array}$ & $\begin{array}{l}\text { myGRaCE deci- } \\
\text { sion support } \\
\text { system [39] and } \\
\text { YouthCHAT } \\
\text { [70] }\end{array}$ & $\begin{array}{l}\text { Improves patient } \\
\text { engagement in un- } \\
\text { derstanding their } \\
\text { situation and in } \\
\text { managing their } \\
\text { treatment. }\end{array}$ \\
\hline $\begin{array}{l}\text { Web-based mental } \\
\text { health self-manage- } \\
\text { ment program with } \\
\text { measures of impact } \\
\text { on suicide risk }\end{array}$ & {$[71-81]$} & $\begin{array}{l}\text { Facilitate } \\
\text { web-based } \\
\text { mood self- } \\
\text { management } \\
\text { and improve } \\
\text { quality of life } \\
\text { through a } \\
\text { cognitive be- } \\
\text { havioral inter- } \\
\text { vention }\end{array}$ & 5 & $\begin{array}{ll}\text { - } & \text { Interactive } \\
\text { website } \\
\text { - } & \begin{array}{l}\text { Psychoeduca- } \\
\text { tion module }\end{array} \\
\text { - } & \text { Multimedia } \\
\text { presentation } \\
\text { - } \quad \text { Web-based } \\
\text { exercises } \\
\text { Discussion } \\
\text { and consulta- } \\
\text { tion forum }\end{array}$ & $\begin{array}{l}\text { - Individu- } \\
\text { als with } \\
\text { low-inten- } \\
\text { sity mental } \\
\text { health } \\
\text { problems }\end{array}$ & $\begin{array}{l}\text { MindSpot Clin- } \\
\text { ic [77] }\end{array}$ & $\begin{array}{l}\text { Program member- } \\
\text { ship rates are rela- } \\
\text { tively low. Individ- } \\
\text { uals tend more of- } \\
\text { ten to experience a } \\
\text { decrease in suicidal } \\
\text { ideation and depres- } \\
\text { sion symptoms. } \\
\text { Programs are of- } \\
\text { fered alone or in } \\
\text { conjunction with } \\
\text { clinical follow-up } \\
\text { by a professional. } \\
\text { Results are hard to } \\
\text { compare. }\end{array}$ \\
\hline $\begin{array}{l}\text { Web-based suicide } \\
\text { prevention training } \\
\text { programs }\end{array}$ & {$[40-42,82-87]$} & $\begin{array}{l}\text { Improve } \\
\text { knowledge, } \\
\text { attitudes and } \\
\text { suicide pre- } \\
\text { vention prac- } \\
\text { tices of profes- } \\
\text { sionals and } \\
\text { sentinels }\end{array}$ & 5 & $\begin{array}{ll}\text { - } & \text { Website } \\
\text { - } & \text { Training } \\
\text { - } & \text { Mudules } \\
& \text { demonstration } \\
\text { - } & \text { Web-based } \\
& \text { exercises }\end{array}$ & $\begin{array}{ll}\text { - } & \text { Profession- } \\
\text { als } \\
\text { - } \quad \text { Sentinels }\end{array}$ & $\begin{array}{l}\text { Question, Per- } \\
\text { suade, Refer, } \\
\text { and Treat pro- } \\
\text { gram }[40,84]\end{array}$ & $\begin{array}{l}\text { These programs al- } \\
\text { low improving } \\
\text { knowledge and atti- } \\
\text { tudes. They seem } \\
\text { less effective in } \\
\text { changing interven- } \\
\text { tion practices if not } \\
\text { offered along with } \\
\text { certain forms of } \\
\text { face-to-face prac- } \\
\text { tices. }\end{array}$ \\
\hline
\end{tabular}

aCT: information and communication technology.

${ }^{b}$ EMPATHY: Empowering a Multimodal Pathway Toward Healthy Youth.

${ }^{\mathrm{c}}$ HEAR: Healer Education Assessment and Referral.

Using ICT to identify individuals at risk for suicide in school (from elementary school to medical school) or community settings has been associated with increased mental health literacy, help-seeking behavior, and use of help resources [63-65]. For example, in the Health Education Assessment and Referral (HEAR) program, medical students anonymously responded to a web-based questionnaire on suicide risk and various mental health issues. The program allowed identifying students at risk for suicide and referring them to a medical school psychiatrist or psychologist through a web-based platform. As a result, the use of medical schools' mental health services increased from $11.5 \%$ to $15 \%$ over 4 years [64].

Our review also identified web-based self-assessment and self-management programs. For example, myGRaCE is a decision-making support system that combines service user self-assessment and practitioner expertise by comparing the

user's self-assessment against a practitioner's assessment [39]. Most of the participants in this study agreed that myGRaCE helped them assess their personal security, understand what puts them in danger, and what areas they should change in their lives. Self-assessment programs are also a way to engage young people and adults by helping them understand their situation and identify ways to take control of their health [39,70]. As for web-based self-management programs, results showed that many programs could, in some cases, significantly reduce suicidal ideation [71-74] and increase chances of resorting to mental health interventions [75,76]. However, the rate of adherence to these types of programs remains low. Examples of these include MoodGYM [71], MindSpot Clinic [77], different types of internet-based cognitive behavioral therapy (iCBT), Thrive [73], the Sadness program [78], and CATCH-IT (Competent Adulthood Transition with Cognitive, Behavioral, 
Humanistic and Interpersonal Training) [74]. These programs were offered either alone or in combination with clinical follow-up. Users seemed to appreciate the mobile apps used for self-management and suicide prevention training. Many web-based suicide prevention programs have been tested for their efficacy. These programs were intended for gatekeepers who work with adolescents [82], gatekeepers in school settings [83], mental health professionals [40], health professionals in general $[41,42,84]$, Veterans Affairs providers [85], and graduate students [86]. In some cases, face-to-face training developed more knowledge and suicide prevention skills than web-based training [84]. In addition, an increase in suicide prevention knowledge was often observed within the first months post training but often decreased over time [82]. Details of the studies that referred to selective suicide prevention strategies are presented in Table 2 .

\section{Indicated Suicide Prevention Strategies}

Regarding the indicated suicide prevention strategies, we selected 52 studies for our review and identified 9 program categories. These programs, presented in Table 3, were offered by health professionals or psychosocial help services and covered suicide risk assessment triage and monitoring, crisis intervention, low-intensity psychological interventions, psychotherapy for individuals at risk for suicide, and technological tools to support face-to-face interventions. The ICTs used for these programs included classification algorithms, chats and text messages, mobile apps, and interactive clinical intervention websites. Examples of these programs include the Mental Health eClinic [55], a web-based assessment and self-management program; Reframe-IT [88], an internet-based CBT program for high school students at risk for suicide; MYPLAN [89], a mobile phone safety plan app for supporting people at risk for suicide; dialectical behavioral therapy Coach Mobile [90], a CBT support intervention mobile phone app; and RAFT (Reconnecting After a Suicide Attempt) [91], a brief web-based outreach intervention for people who attempted suicide and who lost contact with services. In general, ICT-based self-assessment tools have been reported to be as effective in person as in hardcopy format in identifying suicide risk warning signs [92]. 
Table 3. Indicated suicide prevention strategies.

\begin{tabular}{|c|c|c|c|c|c|c|c|}
\hline Type of program & Identified studies & Objectives & Programs, $n$ & $\mathrm{ICT}^{\mathrm{a}}$ used & $\begin{array}{l}\text { Targeted popula- } \\
\text { tion }\end{array}$ & Examples & $\begin{array}{l}\text { Results and com- } \\
\text { ments }\end{array}$ \\
\hline $\begin{array}{l}\text { Development of } \\
\text { web-based sui- } \\
\text { cide risk assess- } \\
\text { ment tools }\end{array}$ & [92-97] & $\begin{array}{l}\text { Propose sui- } \\
\text { cide risk as- } \\
\text { sessment } \\
\text { tools admin- } \\
\text { istered elec- } \\
\text { tronically in } \\
\text { clinical con- } \\
\text { texts }\end{array}$ & 4 & $\begin{array}{ll}\text { - } & \text { Electronic } \\
\text { clinical in- } \\
\text { strument } \\
\text { - } \\
\text { Response } \\
\text { selection al- } \\
\text { gorithm } \\
\text { based on as- } \\
\text { sessment re- } \\
\text { sults }\end{array}$ & $\begin{array}{l}\text { Individu- } \\
\text { als at risk } \\
\text { for suicide } \\
\text { in contact } \\
\text { with health } \\
\text { services }\end{array}$ & $\begin{array}{l}\text { Web-based } \\
\text { Columbia Sui- } \\
\text { cide Severity } \\
\text { Rating Scale } \\
\text { [93] }\end{array}$ & $\begin{array}{l}\text { Electronic assess- } \\
\text { ment tools seem } \\
\text { as effective as } \\
\text { hardcopy ver- } \\
\text { sions. They allow } \\
\text { internet users at } \\
\text { times to reveal } \\
\text { their suicidal be- } \\
\text { haviors more eas- } \\
\text { ily }\end{array}$ \\
\hline $\begin{array}{l}\text { Use of artificial } \\
\text { intelligence and } \\
\text { machine learning } \\
\text { to optimize com- } \\
\text { pletion time for } \\
\text { suicide risk as- } \\
\text { sessment tools }\end{array}$ & {$[98]$} & $\begin{array}{l}\text { - } \\
\text { completion } \\
\text { time for sui- } \\
\text { cide risk as- } \\
\text { sessment } \\
\text { tools }\end{array}$ & 1 & - $\quad \mathrm{CAT}^{\mathrm{b}}$ & $\begin{array}{l}\text { Individu- } \\
\text { als at risk } \\
\text { for suicide } \\
\text { in contact } \\
\text { with health } \\
\text { services }\end{array}$ & CAT [98] & $\begin{array}{l}\text { This type of algo- } \\
\text { rithm allows re- } \\
\text { ducing the num- } \\
\text { ber of items } \\
\text { needed to assess } \\
\text { suicide risk. }\end{array}$ \\
\hline $\begin{array}{l}\text { Use of triage sys- } \\
\text { tems by ICT to } \\
\text { assess suicide } \\
\text { risk }\end{array}$ & [99] & $\begin{array}{l}\text { Improve } \\
\text { triage of in- } \\
\text { dividuals at } \\
\text { risk for sui- } \\
\text { cide who } \\
\text { use health } \\
\text { services }\end{array}$ & 1 & 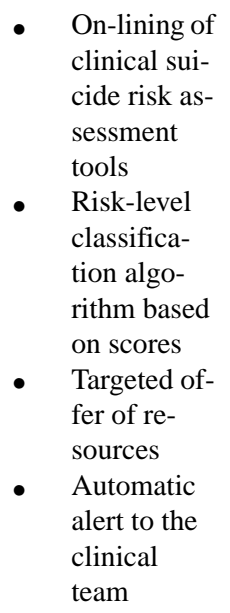 & $\begin{array}{l}\text { Individu- } \\
\text { als at risk } \\
\text { for suicide } \\
\text { in contact } \\
\text { with health } \\
\text { services }\end{array}$ & $\begin{array}{l}\text { Mental health } \\
\text { eClinic [99] }\end{array}$ & $\begin{array}{l}\text { This type of pro- } \\
\text { gram allows } \\
\text { identifying young } \\
\text { people at risk for } \\
\text { suicide and offer- } \\
\text { ing them clinical } \\
\text { treatment more } \\
\text { rapidly. }\end{array}$ \\
\hline $\begin{array}{l}\text { Crisis interven- } \\
\text { tion via text mes- } \\
\text { saging or internet } \\
\text { chatting }\end{array}$ & {$[68,69,84,85]$} & $\begin{array}{l}\text { Intervene in } \\
\text { a crisis situa- } \\
\text { tion via text } \\
\text { messaging } \\
\text { or internet } \\
\text { chatting }\end{array}$ & 3 & $\begin{array}{ll}\text { - } & \text { Text messag- } \\
\text { ing } \\
\text { - } \\
\text { Internet } \\
\text { chatting } \\
\text { - Computer- } \\
\text { ized system } \\
\text { for process- } \\
\text { ing text } \\
\text { messages } \\
\text { and chat ex- } \\
\text { changes }\end{array}$ & $\begin{array}{l}\text { - Young } \\
\text { people are } \\
\text { the priority } \\
\text { target } \\
\text { group of } \\
\text { these inter- } \\
\text { ventions. } \\
\text { They can, } \\
\text { however, } \\
\text { be used to } \\
\text { reach other } \\
\text { age groups }\end{array}$ & $\begin{array}{l}\text { Kids Help } \\
\text { Phone } \\
\text { LIVECHAT } \\
\text { Project [100] } \\
\text { and RAFT }{ }^{\mathrm{c}}[91]\end{array}$ & $\begin{array}{l}\text { Text messages } \\
\text { and internet chat } \\
\text { interventions } \\
\text { seem a viable al- } \\
\text { ternative to tele- } \\
\text { phone interven- } \\
\text { tions for certain } \\
\text { groups. However, } \\
\text { intervention } \\
\text { strategies adapted } \\
\text { to these modes of } \\
\text { communication } \\
\text { need to be devel- } \\
\text { oped. }\end{array}$ \\
\hline $\begin{array}{l}\text { Use of web-based } \\
\text { publications by } \\
\text { patients as inter- } \\
\text { vention support } \\
\text { material }\end{array}$ & {$[101,102]$} & $\begin{array}{l}\text { Assess sui- } \\
\text { cide risk } \\
\text { and inter- } \\
\text { vene using a } \\
\text { person's } \\
\text { web-based } \\
\text { discourse }\end{array}$ & 1 & $\begin{array}{l}\text { - Content of } \\
\text { posts writ- } \\
\text { ten on social } \\
\text { networks }\end{array}$ & $\begin{array}{ll}\text { - } & \text { Suicidal } \\
\text { individuals } \\
\text { receiving } \\
\text { mental } \\
\text { health ser- } \\
\text { vices }\end{array}$ & $\begin{array}{l}\text { Patient's social } \\
\text { networking } \\
\text { sites as a clini- } \\
\text { cal tool [101] }\end{array}$ & $\begin{array}{l}\text { The use of con- } \\
\text { tent written on } \\
\text { social networks } \\
\text { by patients al- } \\
\text { lows a better un- } \\
\text { derstanding of } \\
\text { the situation and } \\
\text { helps perform a } \\
\text { suicide risk as- } \\
\text { sessment, espe- } \\
\text { cially in the case } \\
\text { of patients who } \\
\text { deny such behav- } \\
\text { iors. }\end{array}$ \\
\hline
\end{tabular}




\begin{tabular}{|c|c|c|}
\hline Type of program & Identified studies & Objectives \\
\hline $\begin{array}{l}\text { Web-based man- } \\
\text { agement and low- } \\
\text { intensity interven- } \\
\text { tion for individu- } \\
\text { als at risk for sui- } \\
\text { cide }\end{array}$ & {$[1,31,63,68,88,102-114]$} & $\begin{array}{l}\text { Intervene } \\
\text { with individ- } \\
\text { uals at risk } \\
\text { for suicide } \\
\text { using a cog- } \\
\text { nitive behav- } \\
\text { ioral ap- } \\
\text { proach }\end{array}$ \\
\hline
\end{tabular}

Mobile apps used $\quad[90,115-121]$ as part of treatment follow-up with suicidal individuals

\begin{abstract}
Use of web-based monitoring tools to improve psychological follow-up of individuals at risk for suicide
\end{abstract}

[107,122,123]
Follow-up program by automatic text messages for individuals at risk for suicide
[91,124-126]

- Offer tai-

lored fol-

low-up fol-

lowing a

suicide at-

tempt to in-

crease treat-

ment use

and reduce

suicidal be-

haviors and

self-harm
Programs, n $\quad$ ICT $^{\mathrm{a}}$ used

Targeted popula- Examples

Results and com-

tion

ments

- Interactive

website

- Web-based exercise module

- Discussion forum

- Multimedia presentation

- Interactive mobile app

- Algorithm for providing responses and offering re-

sources based on information provided by the user

- Digitalization of screening tools

- Mobile app

- Contact with intervention team via automated alerts

- Automated sending of text messages

- Automated sending of predrafted text messages, including encouragement and appointment date reminders
- General Reframe-IT These programs population [88], Fitmindkit bring about a - Individu- [102], EMPA- small decrease in als re- $\quad \mathrm{THY}^{\mathrm{d}}$ [63], and suicide risk ferred to SMART $^{\mathrm{e}}$ among partici-

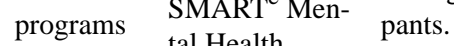
by clinicians Project $[110,113]$

- Individuals receiving mental health services

- Aboriginal young people

DBT $^{\mathrm{f}}$ Coach Mobile [90] and AIMhi Stay Strong iPad [101]

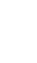

These apps seem to help reduce the danger of suicide and the urgency of self-harm. Perceptions are positive, and apps allow reaching young people in isolated communities.

\begin{tabular}{|c|c|c|}
\hline $\begin{array}{l}\text { Individu- } \\
\text { als diag- } \\
\text { nosed with } \\
\text { a mood } \\
\text { disorder } \\
\text { and receiv- } \\
\text { ing mental } \\
\text { health ser- } \\
\text { vices }\end{array}$ & $\begin{array}{l}\text { Depression } \\
\text { Project [123] }\end{array}$ & $\begin{array}{l}\text { The use of an app } \\
\text { facilitates disclo- } \\
\text { sure of suicidal } \\
\text { and self-harm be- } \\
\text { haviors. Regular } \\
\text { monitoring of } \\
\text { symptoms helps } \\
\text { adjust interven- } \\
\text { tion strategies. }\end{array}$ \\
\hline
\end{tabular}

- Suicidal Postattempt fol- Users appreciate individuals low-up program the text messages receiving by text messag- and deem them a mental ing [124] good way of health ser- keeping in touch vices with care services. Help-seeking behaviors increase, and selfharm behaviors decrease.

\footnotetext{
ICT: information and communication technology.

${ }^{\mathrm{b}} \mathrm{CAT}$ : computerized adaptive testing.

${ }^{\mathrm{c}} \mathrm{RAFT}$ : Reconnecting After a Suicide Attempt.

${ }^{d}$ EMPATHY: Empowering a Multimodal Pathway Toward Healthy Youth.

${ }^{\text {e}}$ SMART: Systematic Medical Appraisal, Referral and Treatment.

${ }^{\mathrm{f}}$ DBT: dialectical behavioral therapy.
}

In some cases, web-based self-assessment tools, as opposed to face-to-face tools, seemed to facilitate the disclosure of suicidal behavior [93]. AI has also been shown to be effective in optimizing the web-based assessment of suicide behavior by using an item response-based computer-adaptive simulation to reduce the length of a suicide risk assessment tool [98]. As for ICT-based triage systems, the use of the Synergy Online System allowed young people to complete a web-based clinical 
assessment before a face-to-face or web-based clinical appointment, who were to be prioritized and contacted immediately in case of high suicide risk [99]. Web-based crisis interventions by chat or SMS text messaging have been on the rise and seem to be an alternative to phone interventions for some groups. Studies comparing chat services with SMS text messaging have shown similar results [127]. However, users of chat services, such as 1130 Online [128], were more likely to be at a high level of suicide crisis, had more mental health problems, were younger, and were more often to be women compared with crisis hotline users. In addition, interventions delivered through chat services were longer and more complicated, and fewer changes were observed in the individual's emotional state [127,128]. Interventions have yet to be developed and adapted to this type of technology; the fact that interventions designed to be delivered by telephone were delivered by chat or SMS text messaging without being adapted to these other media was considered a major limitation [128]. Some studies also analyzed content posts by suicidal patients on social networking sites to better assess suicide risk, especially in patients denying suicidal behavior [101,129]. Although social media content helped with better understanding a person's situation, there were many ethical concerns regarding this data collection method [129].

Self-management and iCBT programs seemed to reduce suicidal ideation. Unlike iCBT and self-management interventions addressing general mental health in the selective suicide prevention section, these interventions specifically addressed user suicide behaviors. Examples of these programs included Empowering a Multimodal Pathway Toward Healthy Youth [63], Reframe-IT [88], Fitmindkit [102], Safe conversation [103], Latitudes [103] and PrevenDep [104]. Intervention goals included developing basic problem-solving skills [88] and cognitive restructuring [105] to reduce suicide risk. Other ICT suicide prevention interventions include using computer alerts or mobile apps to apply a safety plan. These ranged from a system alerting the clinician not to forget to use the safety plan with a patient [130] to a mobile app of a personalized safety plan that patients could have on their phones at all times [89,115]. Research has demonstrated a good level of acceptability [131] for these interventions, but further evaluation of their effects on suicidal behaviors is necessary. Mobile apps have also been used to support therapeutic follow-up for suicidal patients [90,115,116], including for specific groups such as Aboriginals and Torres Strait Island Australians [117]. These mobile apps seemed to help reduce suicidal danger and self-harm [90,118], reach young people in isolated communities [132], and increase adherence to face-to-face follow-ups [119].

\section{Discussion}

\section{Limitations}

The rapid expansion of ICT use in suicide prevention has preceded the development of theoretical models to orient its methods and content and the accumulation of sufficient empirical research to indicate what is most helpful and what is not helpful. In this context, common sense has been the guiding principle, resulting in a plethora of suicide prevention activities being implemented with limited research evaluations of their effectiveness slowly following. Many of the most widely used ICT suicide prevention services have never been evaluated. Therefore, the published studies concern a small nonrandom sample of select interventions that a few researchers have been interested in studying. When little or no research has been published on ICT programs, this does not mean that they are not effective. Similarly, when there are promising empirical data on the benefits of a program, this does not mean that it is better or more useful than programs that have not been studied. Furthermore, we do not know if the promising results reported will stand the test of time, as more research is conducted using more rigorous research methodologies. Therefore, any conclusions drawn from the limited scientific publications must be considered preliminary and hopefully will be subject to verification in the future.

\section{Contributions}

This scoping review on ICT use in suicide prevention shows that a large number of studies have been published in the past few years $[1,3,5]$. Our findings shed light on the use of ICT in different types of universal, selective, and indicated suicide prevention strategies.

Amid publications with the potential to reach a large population, there are only a few publications on the use of ICT in universal suicide prevention [27-35,133]. Our findings reveal that there are around $85 \%$ fewer studies on universal prevention strategies than those on selective and indicated strategies. The 10 publications we identified describe health promotion and suicide prevention through educational websites, web-based awareness campaigns, and social media [27-35,133]. The limited empirical findings suggest that these programs may play a role in increasing general mental health literacy and the incidence of help-seeking behavior, which are associated with reduced suicidal ideation and behavior. However, the effects of these programs on perceptions and knowledge have rarely been investigated. It is important to identify which characteristics of educational websites, awareness campaigns, and postings on social media are associated with positive changes in help seeking and reductions in suicidal ideations and behaviors. Furthermore, it is essential to develop effective means for identifying sites and postings that are helpful and notifying users about or orienting them toward internet content that may be of help to them.

Selective suicide prevention strategies using ICT consist of programs that identify specific subpopulations to offer specialized support to reduce suicide risk. They particularly targeted young people and various at-risk groups (eg, the lesbian, gay, bisexual, transgender, queer, and other community; sexual minorities; and aboriginal communities) through their profiles and linguistic characteristics (eg, chat sessions, web-based written forms, and social media) or by analyzing their medical records and research data. They also include targeted web-based advertising, web-based self-assessment and self-management, and web-based training. A larger published body of research indicates that these approaches are promising, particularly in controlled environments such as schools. School programs using ICT, such as HEAR, have been shown to have a positive impact 
on mental health help seeking and service use in youth [64]. Programs targeting specific subgroups of the general population have been shown to increase mental health literacy and the chances of using mental health services, but this effect seems to decrease over time $[71,73,74,77,92]$. Therefore, it is important to focus on the sustainability of the effects of programs that have an initial positive impact. The novelty of an intervention may be associated with greater effects. If novelty is a key feature of programs' success, then either the programs need to be constantly changed and renewed to sustain their impact or the programs need to be continually replaced by new and different activities to ensure that people will continue to be helped over time. Therefore, both approaches may be proven to be unsustainable over time. This rapid effect can also give a false sense that resorting to web-based strategies is sufficient. However, web-based help does not replace face-to-face or direct support and care from trained professionals. These different selective suicide prevention strategies should only be used in addition to face-to-face type of help and interventions. Moreover, our empirical findings show that more research is required to better distinguish between false positives and false negatives in these web-based identification techniques. It is of utmost importance to help identify at-risk groups and avoid discarding individuals who are assessed as false negatives too quickly. A false impression of security can put these individuals at a greater risk.

Where indicated suicide prevention strategies are concerned, programs vary, including using ICT in suicide risk assessment triage, monitoring suicide risk, crisis intervention activities, and psychotherapy. The programs were offered on the web only (eg, websites, mobile phone apps, and chats), but they were sometimes supported by face-to-face interventions. In some instances, they were found to be efficient (eg, shortened web-based assessments), and sometimes they were time-consuming (eg, interventions were longer in chat sessions). ICT-based and self-management interventions seem promising, as they address suicidal behaviors directly and offer alternatives for coping with suicidal thoughts by developing problem-solving skills [88,90-92]. In addition, specific at-risk groups in isolated communities where other services are not available may benefit from mobile apps used for patient follow-up.

\section{Ethical Considerations to Address in the Future}

Many of the studies included in this review raised security and ethical concerns regarding web-based suicide prevention practices. Ethical concerns range from a lack of training and web-based moderators' skills to the lack of an evidence-based framework providing guidelines for the secure use of ICT [35]. As mentioned by Robinson et al [35], it is ethically necessary to provide security protocols and a clear code of ethics for safe web-based intervention. Another ethical concern is that all individuals have the right to privacy, including web privacy $[101,129]$. Thus, there is reason to question whether the content analysis of web-based social media posts, emails, and other web-based sources of information is an ethical research endeavor if informed consent is not obtained from the individuals who have posted the information [101,129]. Beyond security and privacy, there are many other ethical concerns regarding web-based surveillance, informed consent, communication, controls, and disclosure [134,135]. For example, a proper ethical assessment of risks and benefits to the use of different ICT strategies is rarely, if almost never, considered in the development process. There is also a major ethical concern regarding reducing or eliminating in-person services and replacing them with insufficient web-based solutions that may appear to present better cost-effectiveness without proper in-depth assessment. With this concern, web-based interventions should always be combined with in-person formal help and intervention services. This raises many concerns and provides plenty of grounds for further research aimed at ensuring safer and more ethical use of ICT in suicide prevention.

\section{Conclusions}

As the number of studies on ICT use in suicide prevention is growing, the published literature needs to be reviewed regularly. This scoping review shows that ICT use in suicide prevention provides an interactive, personalized, readily available, and accessible approach to reach various populations for identification of at-risk individuals and to provide support. ICT may provide a sense of being connected to people who are otherwise isolated and reluctant to use offline services. Promising published findings on web-based intervention content includes psychoeducation and skills training. As digital help proliferates, one should consider whether this means that help-seeking and suicide prevention activities will replace traditional offline services. However, in some areas where radical changes were expected, existing modalities continue to be used (eg, individuals did not stop using in-person services when telephone phone crisis lines appeared, and these telephone lines reached a different audience and complemented existing services). The extent to which ICT will become the main source of suicide prevention activities will depend upon its efficacy in helping people, compared with and as a complement to existing services and activities.

Although there is a growing body of evidence regarding ICT use in suicide prevention, program evaluation is still lacking. There is a need for more research evaluating and comparing the impacts of various ICT strategies in different contexts, understanding the profiles of individuals at risk of suicide who use ICT, and web-based help-seeking behaviors. We also need to better understand the impact of ICT on individuals who are bereaved by suicide. Moreover, ethics and security concerns regarding web-based suicide prevention have been the focus of very limited research and need to be addressed in future studies.

Furthermore, service users, providers, and managers from private or public systems should be informed as of now and updated regularly on the benefits and risks of ICT use in health and social services. This information should include (1) effectiveness in various well-described contexts and potential unexpected iatrogenic effects, (2) cost-benefit relationship to the best comparator, (3) access, (4) acceptability and ethical concerns, (5) security, and (6) implementation. Concerning implementation, quality standards should be similar to those of Improving Access to Psychological Therapies standards set by the United Kingdom for access to psychotherapy. These standards are (1) a model of care, (2) access, (3) evidence-based interventions, (4) outcome-based measurement, and (5) the 
provider's training and supervision. International health and social technology assessment agencies should therefore consider developing guidelines and a system of voluntary accreditation for ICT use in suicide prevention. National and regional public health and social services may require that, before commissioning an ICT for suicide prevention or mental health care, their Health Technology Agency recommends ICT based on its efficacy, efficiency, safety, acceptability, and feasibility in the context of jurisdiction.

\section{Acknowledgments}

The authors would like to thank Brian Mishara, Alain Lesage, Jérôme Gaudreault, and the Association Québécoise de prevention du suicide for their valuable and constructive suggestions during the planning and development of this study. A grant was awarded for the completion of the study to RL and CB by the Canadian Institutes of Health Research, Institute of Population and Public Health (grant 385 708). JR received a postdoctoral grant from the Quebec Network on Nursing Intervention Research and the project from the Quebec Network on Suicide, Mood Disorders and Related Disorders.

\section{Conflicts of Interest}

None declared.

\section{Multimedia Appendix 1}

Search strategy syntax specific to each consulted database.

[DOCX File, 15 KB-Multimedia Appendix 1]

\section{References}

1. Larsen ME, Nicholas J, Christensen H. A systematic assessment of smartphone tools for suicide prevention. PLoS One 2016;11(4):e0152285 [FREE Full text] [doi: 10.1371/journal.pone.0152285] [Medline: 27073900]

2. van Spijker BA, Werner-Seidler A, Batterham PJ, Mackinnon A, Calear AL, Gosling JA, et al. Effectiveness of a web-based self-help program for suicidal thinking in an Australian community sample: randomized controlled trial. J Med Internet Res 2018 Feb 14;20(2):e15 [FREE Full text] [doi: 10.2196/jmir.8595] [Medline: 29444769]

3. Perry Y, Werner-Seidler A, Calear A, Christensen H. Web-based and mobile suicide prevention interventions for young people: a systematic review. J Can Acad 2016;25(2):73-79. [Medline: 27274742]

4. de la Torre I, Castillo G, Arambarri J, López-Coronado M, Franco MA. Mobile apps for suicide prevention: review of virtual stores and literature. JMIR mHealth and uHealth 2017 Oct 10;5(10):e130. [doi: 10.2196/mhealth.8036] [Medline: 29017992]

5. Robinson J, Cox G, Bailey E, Hetrick S, Rodrigues M, Fisher S, et al. Social media and suicide prevention: a systematic review. Early Interv Psychiatry 2016 Apr;10(2):103-121. [doi: 10.1111/eip.12229] [Medline: 25702826]

6. Robinson J, Bailey E, Witt K, Stefanac N, Milner A, Currier D, et al. What works in youth suicide prevention? A systematic review and meta-analysis. EClinicalMedicine 2018;4-5:52-91 [FREE Full text] [doi: 10.1016/j.eclinm.2018.10.004] [Medline: $\underline{31193651]}$

7. van Spijker BAJ, van Straten A, Kerkhof AJ. Effectiveness of online self-help for suicidal thoughts: results of a randomised controlled trial. PLoS ONE 2014 Feb 27;9(2):e90118. [doi: 10.1371/journal.pone.0090118]

8. Wagner B, Horn AB, Maercker A. Internet-based versus face-to-face cognitive-behavioral intervention for depression: a randomized controlled non-inferiority trial. J Affect Disord 2014 Jan;152-154:113-121. [doi: 10.1016/j.jad.2013.06.032] [Medline: 23886401]

9. Organisation mondiale de la Santé. Prévention du suicide: l'état d'urgence mondial. Geneva: Organisation mondiale de la Santé; 2014.

10. Le grand dictionnaire terminologique (GDT). Office québécois de la langue française. URL: http://gdt.oqlf.gouv.qc.ca/ [accessed 2020-09-16]

11. Arksey H, O'Malley L. Scoping studies: towards a methodological framework. International Journal of Social Research Methodology 2005 Feb;8(1):19-32. [doi: 10.1080/1364557032000119616]

12. Levac D, Colquhoun H, O'Brien K. Scoping studies: advancing the methodology. Implementation Science 2010;5:69 [FREE Full text] [doi: 10.1186/1748-5908-5-69]

13. Mishara B, Kerkhof AJFM, editors. Suicide Prevention and New Technologies: Evidence-Based Practice. London: Palgrave MacMillan; 2013.

14. Donker T, Petrie K, Proudfoot J, Clarke J, Birch M, Christensen H. Smartphones for smarter delivery of mental health programs: a systematic review. J Med Internet Res 2013 Nov 15;15(11):e247 [FREE Full text] [doi: 10.2196/jmir.2791] [Medline: 24240579]

15. Grist R, Porter J, Stallard P. Mental Health Mobile Apps for Preadolescents and Adolescents: A Systematic Review. J Med Internet Res 2017 May 25;19(5):e176 [FREE Full text] [doi: 10.2196/jmir.7332] [Medline: 28546138] 
16. Shamseer L, Moher D, Clarke M, Ghersi D, Liberati A, Petticrew M, the PRISMA Group. Preferred reporting items for systematic review and meta-analysis protocols (PRISMA-P) 2015: elaboration and explanation. BMJ 2015 Jan 02;349(jan02 1):g7647-g7647 [FREE Full text] [doi: 10.1136/bmj.g7647]

17. Methely A, Campbell S, Chew-Graham C, McNally R, Cheraghi-Sohi S. PICO, PICOS and SPIDER: a comparison study of specificity and sensitivity in three search tools for qualitative systematic reviews. BMC Health Services Research 2014;14(1):1-10 [FREE Full text] [doi: 10.1186/s12913-014-0579-0]

18. Straus SE, Tetroe J, Graham ID, Zwarenstein M, Bhattacharyya O, Shepperd S. Monitoring use of knowledge and evaluating outcomes. Canadian Medical Association Journal 2010 Jan 18;182(2):E94-E98. [doi: 10.1503/cmaj.081335]

19. Pourmand A, Roberon J, Caggiula A, Monsalve N, Rahimi M, Torres-Llenza V. Social media and suicide: a review of technology-based epidemiology and risk assessment. Telemedicine and e-Health 2019;25(10):880-888 [FREE Full text] [doi: $\underline{10.1089 / \text { tmj.2018.0203] }}$

20. Bartels EM. How to perform a systmatic search. Best Practice \& Research Clinical Rheumatology 2013;27(2):295-306 [FREE Full text] [doi: 10.1016/j.berh.2013.02.001]

21. McHugh ML. Interrater reliability: the kappa statistic. Biochem Med (Zagreb) 2012;22(3):276-282 [FREE Full text] [Medline: 23092060]

22. Mishara B, Chagnon F, Daigle M, Balan B, Raymond S, Marcoux I, et al. Comparing models of helper behavior to actual practice in telephone crisis intervention: A silent monitoring study of calls to the US 1-800-SUICIDE network. Suicide and Life-Threatening Behavior 2007;37(3):291-307. [doi: 10.1521/suli.2007.37.3.291]

23. Mishara B, Daigle M. Helplines crisis intervention services: challenges for the future. In: Lester D, editor. Suicide Prevention: resources for the millennium. New York: Routledge; 2001:153-171.

24. Mishara BL, Daigle M, Bardon C, Chagnon F, Balan B, Raymond S, et al. Comparison of the Effects of Telephone Suicide Prevention Help by Volunteers and Professional Paid Staff: Results from Studies in the USA and Quebec, Canada. Suicide Life Threat Behav 2016 Oct;46(5):577-587 [FREE Full text] [doi: 10.1111/sltb.12238] [Medline: 26946110]

25. Henschke N, Ostelo R, Vlaeven S, Morley S, Assendelft W, Main C. Behavioural treatment for chronic low-back pain. Cochrane Database System Reviews.: Cochrane Library; 2010. URL: https://www.ncbi.nlm.nih.gov/pmc/articles/ PMC7065591/pdf/CD002014.pdf [accessed 2020-09-15]

26. Schünemann H, Vist G, Higgins J, Santesso N, Deeks J, Glasziou P, et al. Interpreting results and drawing conclusions. In: Higgins JPT, Thomas J, Chandler J, Cumpston M, Li T, Page MJ, et al, editors. Cochrane Handbook for Systematic Reviews of Interventions, Second Edition. Chichester (UK): John Wiley \& Sons; 2019:403-431.

27. Carli V. Preventing suicidality through online tools: The SUPREME Project. In: Courtet P, editor. Understanding Suicide: from Diagnosis to Personalized Treatment. New York: Springer; 2016:281-289.

28. Wexler L, Gubrium A, Griffin M, DiFulvio G. Promoting Positive Youth Development and Highlighting Reasons for Living in Northwest Alaska Through Digital Storytelling. Health Promotion Practice 2012 Oct 24;14(4):617-623. [doi: $10.1177 / 1524839912462390]$

29. Hurley, SJ. Public pedagogy and the experience of video creators in the It Gets Better Project. Libraries digital conservancy. 2014. URL: https://hdl.handle.net/11299/171186 [accessed 2020-09-16]

30. Rogers ML, Schneider ME, Gai AR, Gorday JY, Joiner TE. Evaluation of two web-based interventions in reducing the stigma of suicide. Behaviour Research and Therapy 2018 Oct;109:49-55. [doi: 10.1016/j.brat.2018.08.001]

31. Robinson J, Bailey E, Hetrick S, Paix S, O'Donnell M, Cox G, et al. Developing Social Media-Based Suicide Prevention Messages in Partnership With Young People: Exploratory Study. JMIR Ment Health 2017 Oct 04;4(4):e40 [FREE Full text] [doi: 10.2196/mental.7847] [Medline: 28978499]

32. Till B, Tran US, Voracek M, Niederkrotenthaler T. Beneficial and harmful effects of educative suicide prevention websites: randomised controlled trial exploring Papageno . Werther effects. Br J Psychiatry 2018 Jan 02;211(2):109-115. [doi: 10.1192/bjp.bp.115.177394]

33. Taylor-Rodgers E, Batterham PJ. Evaluation of an online psychoeducation intervention to promote mental health help seeking attitudes and intentions among young adults: randomised controlled trial. J Affect Disord 2014 Oct 15;168:65-71. [doi: 10.1016/j.jad.2014.06.047] [Medline: 25038293]

34. Berger J. Adolescents on the lookout for suicidal friends on social networking sites. Digital Repository at the University of Maryland.: Doctoral dissertation, University of Maryland, College Park; 2013. URL: https://drum.lib.umd.edu/handle/ 1903/14494 [accessed 2020-09-22]

35. Robinson J, Rodrigues M, Fisher S, Bailey E, Herrman H. Social media and suicide prevention: findings from a stakeholder survey. Shanghai Arch Psychiatry 2015 Feb 25;27(1):27-35 [FREE Full text] [doi: 10.11919/j.issn.1002-0829.214133] [Medline: 25852253]

36. Chen JI, Smolenski DJ, Dobscha SK, Bush NE, Denneson LM. Correlates of Mental Health Smartphone Application Use among Patients with Suicidal Ideation. Journal of Technology in Human Services 2018 Nov 16;36(4):191-207. [doi: $10.1080 / 15228835.2018 .1502119]$

37. Sueki H, Ito J. Suicide prevention through online gatekeeping using search advertising techniques: a feasibility study. Crisis 2015 Jul;36(4):267-273. [doi: 10.1027/0227-5910/a000322] [Medline: 26440623] 
38. Liu NH, Contreras O, Muñoz RF, Leykin Y. Assessing Suicide Attempts and Depression Among Chinese Speakers Over the Internet. Crisis 2014 Sep 01;35(5):322-329. [doi: 10.1027/0227-5910/a000261]

39. Buckingham CD, Adams A, Vail L, Kumar A, Ahmed A, Whelan A, et al. Integrating service user and practitioner expertise within a web-based system for collaborative mental-health risk and safety management. Patient Education and Counseling 2015 Oct;98(10):1189-1196. [doi: 10.1016/j.pec.2015.08.018]

40. Gryglewicz K, Chen JI, Romero GD, Karver MS, Witmeier M. Online Suicide Risk Assessment and Management Training. Crisis 2017 May;38(3):186-194. [doi: 10.1027/0227-5910/a000421]

41. Ryan K, Tindall C, Strudwick G. Enhancing Key Competencies of Health Professionals in the Assessment and Care of Adults at Risk of Suicide Through Education and Technology. Clinical Nurse Specialist 2017;31(5):268-275. [doi: 10.1097/nur.0000000000000322]

42. LeCloux M. The development of a brief suicide screening and risk assessment training webinar for rural primary care practices. Journal of Rural Mental Health 2018 Jan;42(1):60-66. [doi: 10.1037/rmh0000087]

43. Passos IC, Mwangi B, Cao B, Hamilton JE, Wu M, Zhang XY, et al. Identifying a clinical signature of suicidality among patients with mood disorders: A pilot study using a machine learning approach. J Affect Disord 2016 Mar 15;193:109-116 [FREE Full text] [doi: 10.1016/j.jad.2015.12.066] [Medline: 26773901]

44. Cook BL, Progovac AM, Chen P, Mullin B, Hou S, Baca-Garcia E. Novel Use of Natural Language Processing (NLP) to Predict Suicidal Ideation and Psychiatric Symptoms in a Text-Based Mental Health Intervention in Madrid. Computational and Mathematical Methods in Medicine 2016;2016:1-8. [doi: 10.1155/2016/8708434]

45. Pestian J, Grupp-Phelan J, Bretonnel CK, Meyers G, Richey L, Matykiewicz P, et al. A controlled trial using natural language processing to examine the language of suicidal adolescents in the emergency department. Suicide \& Life-Threatening Behavior 2016;46:154-159 [FREE Full text] [doi: 10.1111/sltb.12180]

46. Pestian J, Sorter M, Connolly B, Cohen K, McCullumsmith C, Gee J, et al. A machine learning approach to identifying the thought markers of suicidal subjects: a prospective multicenter trial. Suicide and Life-Threatening Behavior 2017;47:112-121. [doi: $10.1111 /$ sltb.12312]

47. Venek V, Scherer S, Morency L, Rizzo AS, Pestian J. Adolescent Suicidal Risk Assessment in Clinician-Patient Interaction. IEEE Trans. Affective Comput 2017 Apr 1;8(2):204-215. [doi: 10.1109/taffc.2016.2518665]

48. Braithwaite SR, Giraud-Carrier C, West J, Barnes MD, Hanson CL. Validating Machine Learning Algorithms for Twitter Data Against Established Measures of Suicidality. JMIR Ment Health 2016 May 16;3(2):e21 [FREE Full text] [doi: 10.2196/mental.4822] [Medline: 27185366]

49. Cheng Q, Li TM, Kwok C, Zhu T, Yip PS. Assessing Suicide Risk and Emotional Distress in Chinese Social Media: A Text Mining and Machine Learning Study. J Med Internet Res 2017 Jul 10;19(7):e243. [doi: 10.2196/jmir.7276]

50. Guan L, Hao B, Cheng Q, Yip PS, Zhu T. Identifying Chinese Microblog Users With High Suicide Probability Using Internet-Based Profile and Linguistic Features: Classification Model. JMIR Mental Health 2015 May 12;2(2):e17. [doi: 10.2196/mental.4227]

51. Lv M, Li A, Liu T, Zhu T. Creating a Chinese suicide dictionary for identifying suicide risk on social media. PeerJ 2015;3:e1455 [FREE Full text] [doi: 10.7717/peerj.1455] [Medline: 26713232]

52. O'Dea B, Larsen ME, Batterham PJ, Calear AL, Christensen H. A Linguistic Analysis of Suicide-Related Twitter Posts. Crisis 2017;38(5):319-329. [doi: 10.1027/0227-5910/a000443] [Medline: 28228065]

53. Ren F, Kang X, Quan C. Examining Accumulated Emotional Traits in Suicide Blogs With an Emotion Topic Model. IEEE J. Biomed. Health Inform 2016 Sep;20(5):1384-1396. [doi: 10.1109/jbhi.2015.2459683]

54. Hettige NC, Nguyen TB, Yuan C, Rajakulendran T, Baddour J, Bhagwat N, et al. Classification of suicide attempters in schizophrenia using sociocultural and clinical features: A machine learning approach. General Hospital Psychiatry 2017 Jul;47:20-28. [doi: 10.1016/j.genhosppsych.2017.03.001]

55. Batterham PJ, van Spijker BAJ, Mackinnon AJ, Calear AL, Wong Q, Christensen H. Consistency of trajectories of suicidal ideation and depression symptoms: Evidence from a randomized controlled trial. Depress Anxiety 2018 Nov 22;36(4):321-329. [doi: $10.1002 /$ da.22863]

56. Roaten K, Johnson C, Genzel R, Khan F, North CS. Development and Implementation of a Universal Suicide Risk Screening Program in a Safety-Net Hospital System. The Joint Commission Journal on Quality and Patient Safety 2018 Jan;44(1):4-11. [doi: $10.1016 /$ j.jcjq.2017.07.006]

57. Adamou M, Antoniou G, Greasidou E, Lagani V, Charonyktakis P, Tsamardinos I, et al. Toward Automatic Risk Assessment to Support Suicide Prevention. Crisis 2019 Jul;40(4):249-256. [doi: 10.1027/0227-5910/a000561]

58. Silvén Hagström A. 'Suicide stigma' renegotiated: Storytelling, social support and resistance in an Internet-based community for the young suicide-bereaved. Qualitative Social Work 2016 Apr 27;16(6):775-792. [doi: 10.1177/1473325016644039]

59. Burnap P, Colombo G, Amery R, Hodorog A, Scourfield J. Multi-class machine classification of suicide-related communication on Twitter. Online Soc Netw Media 2017;2:32-44 [FREE Full text] [doi: 10.1016/j.osnem.2017.08.001]

60. Du J, Zhang Y, Luo J, Jia Y, Wei Q, Tao C, et al. Extracting psychiatric stressors for suicide from social media using deep learning. BMC Med Inform Decis Mak(Suppl 2) 2018;18:43 [FREE Full text] [doi: 10.1186/s12911-018-0632-8]

61. Coppersmith G, Leary R, Crutchley P, Fine A. Natural Language Processing of Social Media as Screening for Suicide Risk. Biomed Inform Insights 2018 Aug 27;10:117822261879286. [doi: 10.1177/1178222618792860] 
62. Jung H, Park H, Song T. Ontology-Based Approach to Social Data Sentiment Analysis: Detection of Adolescent Depression Signals. J Med Internet Res 2017 Jul 24;19(7):e259. [doi: 10.2196/jmir.7452]

63. Silverstone PH, Bercov M, Suen VYM, Allen A, Cribben I, Goodrick J, et al. Long-term Results from the Empowering a Multimodal Pathway Toward Healthy Youth Program, a Multimodal School-Based Approach, Show Marked Reductions in Suicidality, Depression, and Anxiety in 6,227 Students in Grades 6-12 (Aged 11-18). Front. Psychiatry 2017 May 15;8:81. [doi: 10.3389/fpsyt.2017.00081]

64. Downs N, Feng W, Kirby B, McGuire T, Moutier C, Norcross W, et al. Listening to Depression and Suicide Risk in Medical Students: the Healer Education Assessment and Referral (HEAR) Program. Acad Psychiatry 2014 Apr 5;38(5):547-553. [doi: $10.1007 / \mathrm{s} 40596-014-0115-\mathrm{x}$ ]

65. Haskins J, Carson JG, Chang CH, Kirshnit C, Link DP, Navarra L, et al. The Suicide Prevention, Depression Awareness, and Clinical Engagement Program for Faculty and Residents at the University of California, Davis Health System. Acad Psychiatry 2015 Jun 11;40(1):23-29. [doi: 10.1007/s40596-015-0359-0]

66. Williams D. Consensus-based strategies for using social networking to reduce suicide risk: a Delphi study. In: Doctoral Dissertation. Denver: The University of the Rockies; 2016.

67. King CA, Eisenberg D, Zheng K, Czyz E, Kramer A, Horwitz A, et al. Online suicide risk screening and intervention with college students: a pilot randomized controlled trial. J Consult Clin Psychol 2015 Jun;83(3):630-636 [FREE Full text] [doi: 10.1037/a0038805] [Medline: 25688811]

68. Silverstone PH, Bercov M, Suen VYM, Allen A, Cribben I, Goodrick J, et al. Initial Findings from a Novel School-Based Program, EMPATHY, Which May Help Reduce Depression and Suicidality in Youth. PLoS ONE 2015 May 14;10(5):e0125527. [doi: 10.1371/journal.pone.0125527]

69. Davidson JE, Zisook S, Kirby B, DeMichele G, Norcross W. Suicide Prevention: a healer education and referral program for nurses. JONA: The Journal of Nursing Administration 2018;48(2):85-92. [doi: 10.1097/nna.0000000000000582]

70. Goodyear-Smith F, Martel R, Darragh M, Warren J, Thabrew H, Clark TC. Screening for risky behaviour and mental health in young people: the YouthCHAT programme. Public Health Rev 2017 Oct;38:20 [FREE Full text] [doi: 10.1186/s40985-017-0068-1] [Medline: 29450092]

71. Christensen H, Farrer L, Batterham PJ, Mackinnon A, Griffiths KM, Donker T. The effect of a web-based depression intervention on suicide ideation: secondary outcome from a randomised controlled trial in a helpline. BMJ Open 2013 Jun 28;3(6):e002886. [doi: 10.1136/bmjopen-2013-002886]

72. Mewton L, Andrews G. Cognitive behaviour therapy via the internet for depression: a useful strategy to reduce suicidal ideation. J Affect Disord 2015 Jan 01;170:78-84. [doi: 10.1016/j.jad.2014.08.038] [Medline: 25233243]

73. Whiteside U, Richards J, Steinfeld B, Simon G, Caka S, Tachibana C, et al. Online cognitive behavioral therapy for depressed primary care patients: a pilot feasibility project. Perm J 2014 May;18(2):21-27 [ [FREE Full text] [doi: 10.7812/TPP/13-155] [Medline: 24867546]

74. Saulsberry A, Marko-Holguin M, Blomeke K, Hinkle C, Fogel J, Gladstone T, et al. Randomized Clinical Trial of a Primary Care Internet-based Intervention to Prevent Adolescent Depression: One-year Outcomes. J Can Acad Child Adolesc Psychiatry 2013 May;22(2):106-117 [FREE Full text] [Medline: 23667356]

75. Guille C, Zhao Z, Krystal J, Nichols B, Brady K, Sen S. Web-Based Cognitive Behavioral Therapy Intervention for the Prevention of Suicidal Ideation in Medical Interns: A Randomized Clinical Trial. JAMA Psychiatry 2015 Dec;72(12):1192-1198 [ [FREE Full text] [doi: 10.1001/jamapsychiatry.2015.1880] [Medline: 26535958]

76. Hedman E, Ljótsson B, Kaldo V, Hesser H, El Alaoui S, Kraepelien M, et al. Effectiveness of Internet-based cognitive behaviour therapy for depression in routine psychiatric care. Journal of Affective Disorders 2014 Feb;155:49-58. [doi: 10.1016/j.jad.2013.10.023]

77. Nielssen O, Dear BF, Staples LG, Dear R, Ryan K, Purtell C, et al. Procedures for risk management and a review of crisis referrals from the MindSpot Clinic, a national service for the remote assessment and treatment of anxiety and depression. BMC Psychiatry 2015;15:304 [FREE Full text] [doi: 10.1186/s12888-015-0676-6] [Medline: 26626712]

78. Williams AD, Andrews G. The Effectiveness of Internet Cognitive Behavioural Therapy (iCBT) for Depression in Primary Care: A Quality Assurance Study. PLoS ONE 2013 Feb 22;8(2):e57447. [doi: 10.1371/journal.pone.0057447]

79. Lara MA, Tiburcio M, Aguilar AA, Sánchez-Solís A. A four-year experience with a Web-based self-help intervention for depressive symptoms in Mexico. Rev Panam Salud Publica 2014;35(5-6):399-406 [FREE Full text] [Medline: 25211568]

80. Gleeson J, Lederman R, Wadley G, Bendall S, McGorry P, Alvarez-Jimenez M. Safety and privacy outcomes from a moderated online social therapy for young people with first-episode psychosis. Psychiatric services 2014;65(4):546-550 [FREE Full text] [doi: 10.1176/appi.ps.201300078]

81. Whiteside U, Lungu A, Richards J, Simon GE, Clingan S, Siler J, et al. Designing Messaging to Engage Patients in an Online Suicide Prevention Intervention: Survey Results From Patients With Current Suicidal Ideation. J Med Internet Res 2014 Feb 07;16(2):e42. [doi: 10.2196/jmir.3173]

82. Ghoncheh R, Gould MS, Twisk JW, Kerkhof AJ, Koot HM. Efficacy of Adolescent Suicide Prevention E-Learning Modules for Gatekeepers: A Randomized Controlled Trial. JMIR Ment Health 2016 Jan 29;3(1):e8 [FREE Full text] [doi:

10.2196/mental.4614] [Medline: 26825006] 
83. Lamis DA, Underwood M, D'Amore N. Outcomes of a Suicide Prevention Gatekeeper Training Program Among School Personnel. Crisis 2017 Mar;38(2):89-99. [doi: 10.1027/0227-5910/a000414]

84. Smith AR, Silva C, Covington DW, Joiner TE. An assessment of suicide-related knowledge and skills among health professionals. Health Psychology 2014;33(2):110-119. [doi: 10.1037/a0031062]

85. Marshall E, York J, Magruder K, Yeager D, Knapp R, De Santis ML, et al. Implementation of Online Suicide-Specific Training for VA Providers. Acad Psychiatry 2014 Feb 22;38(5):566-574. [doi: 10.1007/s40596-014-0039-5]

86. Krieg C. Can demonstration enhance the effects of an online risk assessment training workshop? Doctoral dissertation, Counseling Psychology. Arizona State University. ASU Library. Digital Repository. 2017. URL: https://repository.asu.edu/ items/40196 [accessed 2020-09-17]

87. Rigsbee N. Suicide assessment training in counselor education. Doctoral dissertation. University of New Mexico. UNM Digital Repository. Albuquerque, New Mexico: The University of New Mexico; 2015. URL: https://tinyurl.com/3vzfr7bs [accessed 2020-09-17]

88. Robinson J, Hetrick S, Cox G, Bendall S, Yuen HP, Yung A, et al. Can an Internet-based intervention reduce suicidal ideation, depression and hopelessness among secondary school students: results from a pilot study. Early Interv Psychiatry 2016 Feb;10(1):28-35. [doi: 10.1111/eip.12137] [Medline: 24684946]

89. Skovgaard Larsen JL, Frandsen H, Erlangsen A. MYPLAN - A Mobile Phone Application for Supporting People at Risk of Suicide. Crisis 2016 May;37(3):236-240. [doi: 10.1027/0227-5910/a000371]

90. Rizvi S, Hughes C, Thomas M. The DBT Coach mobile application as an adjunct to treatment for suicidal and self-injuring individuals with borderline personality disorder: a preliminary evaluation and challenges to client utilization. Psychological Services 2016;13(4):380-388. [doi: $10.1037 / \mathrm{ser} 0000100$ ]

91. Larsen ME, Shand F, Morley K, Batterham PJ, Petrie K, Reda B, et al. A Mobile Text Message Intervention to Reduce Repeat Suicidal Episodes: Design and Development of Reconnecting After a Suicide Attempt (RAFT). JMIR Ment Health 2017 Dec 13;4(4):e56. [doi: 10.2196/mental.7500]

92. AL-Asadi AM, Klein B, Meyer D. Multiple Comorbidities of 21 Psychological Disorders and Relationships With Psychosocial Variables: A Study of the Online Assessment and Diagnostic System Within a Web-Based Population. J Med Internet Res 2015 Feb 26;17(3):e55. [doi: 10.2196/jmir.4143]

93. Hesdorffer DC, French JA, Posner K, DiVentura B, Pollard JR, Sperling MR, et al. Suicidal ideation and behavior screening in intractable focal epilepsy eligible for drug trials. Epilepsia 2013 Feb 28;54(5):879-887. [doi: 10.1111/epi.12128]

94. Best P, Foye U, Taylor B, Hazlett D, Manktelow R. Online interactive suicide support services: quality and accessibility. Mental Health Review Journal 2013 Nov 29;18(4):226-239. [doi: 10.1108/mhrj-03-2013-0009]

95. Flamarique I, Santosh P, Zuddas A, Arango C, Purper-Ouakil D, Hoekstra P, STOP consortium. Development and psychometric properties of the Suicidality: Treatment Occurring in Paediatrics (STOP) Suicidality Assessment Scale (STOP-SAS) in children and adolescents. BMC pediatrics 2016;16(1):213 [FREE Full text] [doi: 10.1186/s12887-016-0751-2]

96. Hirschhorn E. Integrating technology into collaborative suicide risk assessment: comparing electronic and paper-and-pencil versions of the suicide status form. In: Doctoral dissertation. Washington D.C: Catholic University of America; 2017.

97. AL-Asadi AM, Klein B, Meyer D. Comorbidity Structure of Psychological Disorders in the Online e-PASS Data as Predictors of Psychosocial Adjustment Measures: Psychological Distress, Adequate Social Support, Self-Confidence, Quality of Life, and Suicidal Ideation. J Med Internet Res 2014 Oct 28;16(10):e248. [doi: 10.2196/jmir.3591]

98. De Beurs DP, de Vries AL, de Groot MH, de Keijser J, Kerkhof AJ. Applying Computer Adaptive Testing to Optimize Online Assessment of Suicidal Behavior: A Simulation Study. J Med Internet Res 2014 Sep 11;16(9):e207. [doi: 10.2196/jmir.3511]

99. Iorfino F, Davenport TA, Ospina-Pinillos L, Hermens DF, Cross S, Burns J, et al. Using New and Emerging Technologies to Identify and Respond to Suicidality Among Help-Seeking Young People: A Cross-Sectional Study. J Med Internet Res 2017 Jul 12;19(7):e247. [doi: 10.2196/jmir.7897]

100. Haner D, Pepler D. "Live Chat" Clients at Kids Help Phone: Individual Characteristics and Problem Topics. J Can Acad Child Adolesc Psychiatry 2016;25(3):138-144 [FREE Full text] [Medline: 27924143]

101. Bennett A, Pourmand A, Shokoohi H, Shesser R, Sanchez J, Joyce J. Impacts of Social Networking Sites on Patient Care in the Emergency Department. Telemedicine and e-Health 2014 Jan;20(1):94-96. [doi: 10.1089/tmj.2013.0055]

102. Batterham PJ, Calear AL, Farrer L, McCallum SM, Cheng VWS. FitMindKit : Randomised controlled trial of an automatically tailored online program for mood, anxiety, substance use and suicidality. Internet Interventions 2018 Jun;12:91-99. [doi: 10.1016/j.invent.2017.08.002]

103. Rice S, Robinson J, Bendall S, Hetrick S, Cox G, Bailey E, et al. Online and Social Media Suicide Prevention Interventions for Young People: A Focus on Implementation and Moderation. J Can Acad Child Adolesc Psychiatry 2016;25(2):80-86 [FREE Full text] [Medline: 27274743]

104. Bresó A, Martínez-Miranda J, Botella C, Baños R, García-Gómez J. Usability and acceptability assessment of an empathic virtual agent to prevent major depression. Expert Systems: International Journal of Knowledge Engineering and Neural Networks 2016;33(4):297-312. [doi: 10.1111/exsy.12151] 
105. Madsen T, van Spijker B, Karstoft K, Nordentoft M, Kerkhof AJ. Trajectories of Suicidal Ideation in People Seeking Web-Based Help for Suicidality: Secondary Analysis of a Dutch Randomized Controlled Trial. J Med Internet Res 2016 Jun 30;18(6):e178. [doi: 10.2196/jmir.5904]

106. Hetrick SE, Goodall J, Yuen HP, Davey CG, Parker AG, Robinson J, et al. Comprehensive Online Self-Monitoring to Support Clinicians Manage Risk of Suicide in Youth Depression. Crisis 2017 May;38(3):147-157. [doi: 10.1027/0227-5910/a000422]

107. Hetrick SE, Yuen HP, Bailey E, Cox GR, Templer K, Rice SM, et al. Internet-based cognitive behavioural therapy for young people with suicide-related behaviour (Reframe-IT): a randomised controlled trial. Evid Based Mental Health 2017 Jul 12;20(3):76-82. [doi: 10.1136/eb-2017-102719]

108. Batterham PJ, Christensen H, Mackinnon AJ, Gosling JA, Thorndike FP, Ritterband LM, et al. Trajectories of change and long-term outcomes in a randomised controlled trial of internet-based insomnia treatment to prevent depression. BJPsych open 2018 Jan 02;3(5):228-235. [doi: 10.1192/bjpo.bp.117.005231]

109. Wilksch SM, O'Shea A, Wade TD. Depressive symptoms, alcohol and other drug use, and suicide risk: Prevention and treatment effects from a two-country online eating disorder risk reduction trial. Int J Eat Disord 2018 Dec 23;52(2):132-141. [doi: $10.1002 /$ eat.23005]

110. Maulik PK, Kallakuri S, Devarapalli S. Operational challenges in conducting a community-based technology-enabled mental health services delivery model for rural India: Experiences from the SMART Mental Health Project. Wellcome Open Res 2018 Apr 18;3:43. [doi: 10.12688/wellcomeopenres.14524.1]

111. Reins JA, Boß L, Lehr D, Berking M, Ebert DD. The more I got, the less I need? Efficacy of Internet-based guided self-help compared to online psychoeducation for major depressive disorder. Journal of Affective Disorders 2019 Mar;246:695-705. [doi: $10.1016 /$ j.jad.2018.12.065]

112. Richards D, Duffy D, Burke J, Anderson M, Connell S, Timulak L. Supported Internet-Delivered Cognitive Behavior Treatment for Adults with Severe Depressive Symptoms: A Secondary Analysis. JMIR Ment Health 2018 Oct 02;5(4):e10204. [doi: $\underline{10.2196 / 10204]}$

113. Tewari A, Kallakuri S, Devarapalli S, Jha V, Patel A, Maulik PK. Process evaluation of the systematic medical appraisal, referral and treatment (SMART) mental health project in rural India. BMC Psychiatry 2017 Dec 4;17(1):385. [doi: $10.1186 / \mathrm{s} 12888-017-1525-6]$

114. Wilks CR, Lungu A, Ang SY, Matsumiya B, Yin Q, Linehan MM. A randomized controlled trial of an Internet delivered dialectical behavior therapy skills training for suicidal and heavy episodic drinkers. Journal of Affective Disorders 2018 May;232:219-228. [doi: 10.1016/j.jad.2018.02.053]

115. Labelle R, Bibaud-De SA, Leblanc F. Innovating to treat depressionprevent suicide: the IPhone@ PSY ASSISTANCE application. In: Mishara B, Kerkhof AJFM, editors. Suicide Prevention and New Technologies: Evidence-Based Practices. London: Palgrave Macmillan; 2013:166-180.

116. Bush NE, Dobscha SK, Crumpton R, Denneson LM, Hoffman JE, Crain A, et al. A Virtual Hope Box smartphone app as an accessory to therapy: proof-of-concept in a clinical sample of veterans. Suicide Life Threat Behav 2015 Feb;45(1):1-9. [doi: 10.1111/sltb.12103] [Medline: 24828126 ]

117. Povey J, Mills PPJR, Dingwall KM, Lowell A, Singer J, Rotumah D, et al. Acceptability of Mental Health Apps for Aboriginal and Torres Strait Islander Australians: A Qualitative Study. J Med Internet Res 2016;18(3):e65 [FREE Full text] [doi: 10.2196/jmir.5314] [Medline: 26969043]

118. Mackie C, Dunn N, MacLean S, Testa V, Heisel M, Hatcher S. A qualitative study of a blended therapy using problem solving therapy with a customised smartphone app in men who present to hospital with intentional self-harm. Evid Based Mental Health 2017 Oct 13;20(4):118-122. [doi: 10.1136/eb-2017-102764]

119. Mok K, Jorm AF, Pirkis J. Who Goes Online for Suicide-Related Reasons? Crisis 2016 Mar;37(2):112-120. [doi: 10.1027/0227-5910/a000366]

120. Hetrick SE, Robinson J, Burge E, Blandon R, Mobilio B, Rice SM, et al. Youth Codesign of a Mobile Phone App to Facilitate Self-Monitoring and Management of Mood Symptoms in Young People With Major Depression, Suicidal Ideation, and Self-Harm. JMIR Ment Health 2018 Jan 23;5(1):e9 [FREE Full text] [doi: 10.2196/mental.9041] [Medline: 29362208]

121. O'Toole M, Arendt M, Pedersen C. Testing an app-assisted treatment for suicide prevention in a randomized controlled trial: effects on suicide risk and depression. Behavior Therapy 2019;50(2):421-429 [FREE Full text] [doi: 10.1016/j.beth.2018.07.007]

122. Hetrick SE, Dellosa MK, Simmons MB, Phillips L. Development and pilot testing of an online monitoring tool of depression symptoms and side effects for young people being treated for depression. Early Intervention in Psychiatry 2014 Feb 25;9(1):66-69. [doi: 10.1111/eip.12127]

123. Chen RY, Feltes JR, Tzeng WS, Lu ZY, Pan M, Zhao N, et al. Phone-Based Interventions in Adolescent Psychiatry: A Perspective and Proof of Concept Pilot Study With a Focus on Depression and Autism. JMIR Res Protoc 2017 Jun 16;6(6):e114. [doi: 10.2196/resprot.7245]

124. Berrouiguet S, Gravey M, Le Galudec M, Alavi Z, Walter M. Post-acute crisis text messaging outreach for suicide prevention: A pilot study. Psychiatry Research 2014 Jul;217(3):154-157. [doi: 10.1016/j.psychres.2014.02.034] 
125. Kodama T, Syouji H, Takaki S, Fujimoto H, Ishikawa S, Fukutake M, et al. Text messaging for psychiatric outpatients: effect on help-seeking and self-harming behaviors. Journal of Psychosocial Nursing and Mental Health Services 2016;54(4):31-37 [FREE Full text] [doi: 10.3928/02793695-20160121-01]

126. Owens $\mathrm{C}$, Charles N. Implementation of a text-messaging intervention for adolescents who self-harm (TeenTEXT): a feasibility study using normalisation process theory. Child and Adolescent Psychiatry and Mental Health 2016;10(1):14 [FREE Full text] [doi: 10.1186/s13034-016-0101-z]

127. Predmore Z, Ramchand R, Ayer L, Kotzias V, Engel C, Ebener P, et al. Expanding Suicide Crisis Services to Text and Chat. Crisis 2017 Jul;38(4):255-260. [doi: 10.1027/0227-5910/a000460]

128. Mokkenstorm JK, Eikelenboom M, Huisman A, Wiebenga J, Gilissen R, Kerkhof AJFM, et al. Evaluation of the 1130 Online Suicide Prevention Crisis Chat Service: Outcomes, Helper Behaviors and Comparison to Telephone Hotlines. Suicide Life Threat Behav 2016 Aug 19;47(3):282-296. [doi: 10.1111/sltb.12286]

129. Ahuja AK, Biesaga K, Sudak DM, Draper J, Womble A. Suicide on facebook. J Psychiatr Pract 2014 Mar;20(2):141-146. [doi: 10.1097/01.pra.0000445249.38801.d1] [Medline: 24638049]

130. Reyes-Portillo JA, Chin EM, Toso-Salman J, Blake Turner J, Vawdrey D, Mufson L. Using Electronic Health Record Alerts to Increase Safety Planning with Youth At-Risk for Suicide: A Non-randomized Trial. Child Youth Care Forum 2018 Jan 24;47(3):391-402. [doi: 10.1007/s10566-018-9435-4]

131. Kennard BD, Biernesser C, Wolfe KL, Foxwell AA, Craddock Lee SJ, Rial KV, et al. Developing a Brief Suicide Prevention Intervention and Mobile Phone Application: A Qualitative Report. Journal of Technology in Human Services 2015 Dec 14;33(4):345-357. [doi: 10.1080/15228835.2015.1106384]

132. Tan Z, Liu X, Liu X, Cheng Q, Zhu T. Designing Microblog Direct Messages to Engage Social Media Users With Suicide Ideation: Interview and Survey Study on Weibo. J Med Internet Res 2017 Dec 12;19(12):e381. [doi: 10.2196/jmir.8729]

133. LeMay R. Student learning of violence prevention education concepts: a longitudinal analysis. Doctoral Dissertation. 2015. URL: https://www.semanticscholar.org/paper/Student-Learning-of-Violence-Prevention-Education-A-LeMay/ 5217862648ffdff4702a835be8497d502f237393\#citing-papers [accessed 2020-09-17]

134. de Andrade NNG, Pawson D, Muriello D, Donahue L, Guadagno J. Ethics and artificial intelligenceuicide prevention on Facebook. Philosophy \& Technology 2018;31(4):669-684. [doi: 10.1007/s13347-018-0336-0]

135. McKernan LC, Clayton EW, Walsh CG. Protecting Life While Preserving Liberty: Ethical Recommendations for Suicide Prevention With Artificial Intelligence. Front. Psychiatry 2018 Dec 3;9:650. [doi: 10.3389/fpsyt.2018.00650]

\section{Abbreviations}

AI: artificial intelligence

CBT: cognitive behavioral therapy

HEAR: Health Education Assessment and Referral

iCBT: internet-based cognitive behavioral therapy

ICT: information and communication technology

PICO: population, intervention, comparison, and outcomes

PRISMA: Preferred Reporting Items for Systematic Reviews and Meta-Analyses

Edited by R Kukafka; submitted 26.10.20; peer-reviewed by N Maltais, E Bailey, K Baudin; comments to author 16.12.20; revised
version received 10.02.21; accepted 16.03.21; published 04.05.21
Please cite as:
Rassy J, Bardon C, Dargis L, Côté LP, Corthésy-Blondin L, Mörch CM, Labelle R
Information and Communication Technology Use in Suicide Prevention: Scoping Review
JMed Internet Res 2021;23(5):e25288
URL: $\underline{\text { https://www.jmir.org/2021/5/e25288 }}$
doi: $\underline{10.2196 / 25288}$
PMID: $\underline{3820754}$

CJessica Rassy, Cécile Bardon, Luc Dargis, Louis-Philippe Côté, Laurent Corthésy-Blondin, Carl-Maria Mörch, Réal Labelle. Originally published in the Journal of Medical Internet Research (https://www.jmir.org), 04.05.2021. This is an open-access article distributed under the terms of the Creative Commons Attribution License (https://creativecommons.org/licenses/by/4.0/), which permits unrestricted use, distribution, and reproduction in any medium, provided the original work, first published in the Journal of Medical Internet Research, is properly cited. The complete bibliographic information, a link to the original publication on https://www.jmir.org/, as well as this copyright and license information must be included. 